\title{
Relevansi Penyusunan Teori Diplomasi Dalam Perspektif Islam
}

\author{
Tika Dian Pratiwi \\ Magister Ilmu Hubungan Internasional \\ Universitas Muhammadiyah Yogyakarta \\ ptikadian@gmail.com
}

\begin{abstract}
Abstrak
Diplomasi dewasa ini dipahami sebagai aktivitas negosiasi antar-negara atau antar-aktor hubungan internasional.Sayangnya, diplomasi konvensional yang dikenal saat ini memiliki beberapa kelemahan, sehingga perlu terobosan baru diplomasi yang melibatkan aktor lain dan akhirnya menghasilkan diplomasi bersih. Diplomasi bersih tidak hanya mengutamakan tujuan, tetapi sarana dan semua proses negosiasi juga diperhatikan dan sama pentingnya dengan tujuan.

Diplomasi bersih melalui perspektif Islam tertuang dalam Al-Qur'an dan Hadist serta diwujudkan dalam pemikiran serta tindakan Nabi Muhammad SAW dalam menyikapi dan menyelesaikan berbagai permasalahan. Pada masa ini, diplomasi bersih juga tergambar dalam diplomasi terbuka yang menjunjung nilai keadilan dan ketransparanan proses serta hasilnya.

Diplomasi bersih memiliki karakteristik yang adil dan rahmatan lil 'alamin membuat berbagai pihak berada pada kedudukan yang sama, tanpa ada penindasan ataupun supremasi dari pihak tertentu. Hasil yang dicapai melalui diplomasi bersih juga akan membuat semua pihak merasa puas. Hal ini pada akhirnya akan membuat jalinan silaturahmi antar pihak semakin kuat dan harmonis.
\end{abstract}

Kata Kunci: Diplomasi, Perspektif Islam, Transparan, Adil.

\begin{abstract}
Diplomacy is generally defined as a negotiation process between countries or amongactors ininternational relations. Conventional diplomacy has some
\end{abstract}


weaknesses that should be resolved and creating a clean diplomacy. A clean diplomacy is not merely focuses on objective policy, but alsopay a more attention on negotiation processes during the policy formulationwhich also considered as important goal.

The clean diplomacy in theIslamic perspective is describedin the Qur'an and Hadith that has beenarticulated in the thoughts and actions of the Prophet Muhammad SAW in addressing and resolving various problems. At this time, the clean diplomacy is also reflected in the open diplomacy that upholds the value of justice, transparency and the results.

The clean diplomacy has a specificcharacteristic namely justice and rahmatan lil 'alaminthat perceive people in the same position in front of God and law, without any discrimination and superiority among parties. The achieved results through a clean diplomacy will also make all parties feel more satisfy. Therefore, the clean diplomacy will improve the relationship between parties became stronger and more harmonious.

Keywords: clean diplomacy, Islamic perspective, transparency, fairness.

\section{Pendahuluan}

Dalam makalah ini, penulis akan menelaah teori diplomasi dalam perspektif Islam. Namun sebelum itu, kita harus paham terlebih dahulu mengenai pengertian diplomasi. Dalam Kamus Oxford diplomasi adalah berbagai cara yang diterapkan oleh duta-duta besar dan utusan-utusannya dalam mengelola ataupun mengatur hubungan yang sudah terjalin dengan negara atau pihak lain. Diplomasi dapat dikatakan sebagai pengelolaan hubungan internasional melalui perundingan; tugas atau ekspresi seni dari para diplomat. Dalam prosesnya, diplomasi mengharuskan sang diplomat untuk melakukan seni permainan kata-kata, agar tujuannya dapat tercapai dengan baik. Namun, dalam berdiplomasi terkadang dituntut pula untuk melakukan tekanan dan ancaman. Hal ini merupakan cara terakhir yang dapat dilakukan apabila tidak ditemukan jalan keluar yang lainnya(Rumintang, 2008: 28).

Diplomat yang melakukan diplomasi merupakan perwakilan dari suatu negara dan membawa kepentingan negara beserta warga negaranya. Hal yang tidak mengherankan, jika para diplomat 
melakukan berbagai macam cara agar tujuannya dapat tercapai, karena tujuan yang ia bawa tersebut merupakan misi negaranya. Hal ini lambat laun menjadi hal yang dipandang kurang baik karena diplomasi terlihat seperti menghalalkan berbagai macam cara dalam mencapai tujuan. Termasuk di dalamnya berbohong serta memainkan kata dan kalimat yang mengesampingkan kebenaran.

Dalam perkembangannya, terdapat berbaga jenis diplomasi, yaitu preventive diplomacy, offensive diplomacy, diplomasi rahasia, public diplomacy, serta berbagai jenis diplomasi lainnya.Preventive diplomacy memiliki tujuan untuk meredakan berbagai pihak yang terlibat dalam masalah agar tidak menimbulkan perang (Snow dan Brown, 2000: 442). Diplomasi preventif biasanya dilakukan oleh negara-negara yang memiliki power menengah ke bawah untuk menghindari campur tangan dari negara super power. Diplomasi jenis ini dilakukan dengan berbagai metode dan cara yang damai agar permasalahan dapat terselesaikan tanpa adanya kekerasan.

Diplomasi yang kedua adalah offensive diplomacy. Offensive diplomacy merupakan teknik diplomasi yang menggunakan tekanan, paksaan, serta ancaman terhadap pihak lain. Dengan menggunakan cara-cara yang memaksa dan menekan mengakibatkan suatu pihak tunduk dan patuh kepada pihak lainnya (Levy, 2008: 539). Ancaman dan tekanan tersebut bisa dalam bentuk embargo ekonomi, pemberhentian bantuan, ancaman militer ataupun sanksi perdagangan.

Diplomasi ketiga adalah diplomasi rahasia yang dilakukan secara diam-diam oleh pemerintah dari suatu negara dan diplomasi ini dirahasiakan dari publik (Momengoh, 2013: 10).Diplomasi rahasia berkembang pada masa abad pertengahan dan biasa digunakan oleh kerajaan-kerajaan, khususnya di Eropa.Kelebihan dari diplomasi ini adalah terjaminnya rahasia dan masalah dapat diselesaikan dengan cepat.

Jenis diplomasi yang keempat adalah public diplomacy yang biasanya digunakan pemerintah untuk membentuk opini publik dan bertujuan untuk mendapat simpati dan dukungan rakyat. Dengan demikian, public diplomacyadalah proses diplomasi yang dilakukan oleh pemerintah kepada masyarakat di negaranya, atau kepada masyarakat di negara lain(D'Hooghe, 2007).

Diplomasi meski memiliki jenis 
yang berbeda, tetapi memiliki tujuan yang sama. Tujuan dari diplomasi dapat dilihat dari berbagai sisi. Mulai dari sisi politik, diplomasi berkaitan dengan kebebasan politik serta bertujuan mempertahankan integritas teritorial suatu negara. Dalam konteks Indonesia, diplomasi bertujuan untuk mempertahankan kemerdekaan yang telah diperoleh serta melindungi kedaulatan teritorial Indonesia mulai dari Sabang hingga Merauke. Dari sisi ekonomi, diplomasi bertujuan untuk memperlancar pembangunan ekonomi nasional. Dari sisi kultur atau budaya, fungsi diplomasi adalah melestarikan dan memperkenalkan kebudayaan nasional di kanca internasional(Roy, 1991: 5-13).

Dewasa ini jenis diplomasi semakin berkembang karena disesuaikan dengan zaman dan kebutuhan. Salah satu jenis diplomasi yang baru dalam kancah hubungan internasional dan politik luar negeri adalah diplomasi bersih. Hadirnya diplomasi bersih merupakan bentuk positif dari diplomasi pada umumnya yang terkenal kurang sesuai dengan nilai-nilai Islam. Dengan adanya diplomasi jenis ini, maka diplomasi dapat ditelaah dalam perspektif Islam yang diharapkan mampu mengurangi efek buruk atau efek negatif dalam teori diplomasi itu sendiri.

\section{Studi Pustaka}

"Diplomasi Bersih" Dalam Perspektif Islam oleh Tulus Warsito dan Surwandono

Teori diplomasi bersih pernah diulas dan ditulis oleh dua orang dosen Universitas Muhammadiyah, yaitu Prof. Dr. Tulus Warsito dan Dr. Surwandono dengan judul "Diplomasi Bersih" Dalam Perspektif Islam.Dalam tulisan tersebut, diplomasi bersih merujuk pada diplomasi yang pelaksanaannya harus sesuai dengan yang diidealkan. Diplomasi bersih terkait dengan konsistensi tanggungjawab kepada umat, sesuai tuntutan Al-Qur'an dan Hadist.Berdasarkan pengertian tersebut, maka diplomasi tidak hanya mengutamakan kepentingan elite, tetapi lebih mengutamakan kepentingan umat dan dapat bermanfaat bagi semua pihak atau rahmatan lil 'alamin yaitu bagi diri sendiri, musuh, maupun bagi alam semesta (Warsito dan Surwandono, 2015: 150).

Dalam hukum Islam, ketika kita melakukan negosiasi dan diplomasi dalam keadaan perang ataupun damai, hak-hak musuh tetap diperhatikan dan dipenuhi sesuai dengan ajaran Al-Qur'an 
dan Sunnah. Dalam hukum internasional Islam, segala peraturan dibuat dengan seadil-adilnya. Regulasi atau aturan ini tidak hanya berlaku bagi negara-negara Islam, tetapi juga bagi negara non-Islam. Dalam tulisan ini, juga diulas mengenai konsep negosiasi Fisher-Ury yang adil dan efektif. Intisari dari konsep tersebut adalah sangat penting bagi dua pihak yang bersengketa memahami perspektif masing-masing mengenai apa yang mereka sengketakan. Apabila ada salah satu pihak yang memaksakan kehendaknya, maka pihak ini tidak melakukan perundingan, melainkan pemaksaan. Dalam mengkonstruksi solusi, peran atau partisipasi kedua belah pihak harus sangat diperhatikan. Semakin besar partisipasi suatu pihak dalam kontribusi usulan kesepakatan, maka semakin besar pula tanggungjawabnya untuk melaksanakan dan menjalankan hasil kesepakatan tersebut(Warsito dan Surwandono, 2015: 151-153).

Dalam membedakan antara diplomasi/negosiasi konvensional dengan diplomasi bersih dalam perspektif Islam, dapat terlihat dari perbedaan istilah pihakpihak yang bersengketa. Jika pada diplomasi konvensional aktor yang terlibat adalah negara-bangsa, maka dalam Islam terkhusus pada zaman Nabi Muhammad, aktor yang terlibat adalah antar-pihak atau antar-golongan. Pada zaman Nabi Muhammad, perjanjian pertama yang dilakukan adalah Piagam Madinah.Ini merupakan kesepakatan pertama di dalam Islam yang ditandatangani oleh Muhammad dan mereformasi secara fundamental konsep sebuah negara yang berdasarkan keimanan. Madinah kala itu menjadi negara yang merangkul masyarakat dari berbagai agama dan keyakinan karena kebebasan beragama sangat dihargai dan dijamin.Meski demikian, masyarakat Madinah memiliki loyalitas pada ikatan politik yang satu. Orang-orang Yahudi di Madinah juga mendapatkan perlakuan yang setara atau sama (equality, musawat) karena orang Yahudi yang berasal dari Bani Auf dianggap bersaudara dengan kaum Muslimin (Warsito dan Surwandono, 2015: 154-155).

Selain bentuk diplomasi bersih yang dijelaskan melalui Piagam Madinah, Tulus Warsito dan Surwandono juga menghadirkan cara Rasulullah bernegosiasi dan berdiplomasi secara baik dan benar melalui Perang Badar, Perang Uhud dan Perjanjian Hudaibiyah. Keempat contoh praktis ini dirasa cukup 
untuk mewakili pandangan Islam mengenai diplomasi bersih.Dengan demikian, kesimpulan dari tulisan Tulus Warsito dan Surwandono mengenai diplomasi bersih menyatakan bahwa pelaksanaan diplomasi harus mengutamakan kepentingan semua pihak yang terlibat dalam sengketa. Berdasarkan rezim internasional yang berlaku, negosiasi bersih harus memenuhi azas akuntabilitas, transparan serta adil bagi diri sendiri maupun bagi pihak lawan (Warsito dan Surwandono, 2015: 151).

Diplomasi bersih juga pernah ditulis oleh Dr. Afzal Iqbal dalam buku yang berjudul Diplomasi Islam.Dalam buku ini, dijelaskan mengenai prinsip-prinsip negosiasi yang adil melalui sikap Nabi Muhammad dalam bernegosiasi dan mengambil keputusan. Catatan pertama mengenai tindakan diplomatik yang dilakukan oleh Muhammad adalah ketika beliau berusia 35 tahun. Kala itu beliau menengahi sebuah konflik (perbedaan pendapat) yang terjad saat rekonstruksi Ka'bah yang diwarisi kaum Quraisy dari Nabi Ibrahim, hampir selesai dikerjakan. Konflik (perbedaan pendapat) bermula ketika para ketua suku dan kabilah yang bekerja dengan keras sama-sama menyatakan berhak meletakkan batu Hajar Aswad. Oleh Nabi Muhammad masalah tersebut diselesaikan dengan sehelai selendang yang di bagian tengahnya diletakkan batu Hajar Aswad tersebut.Seluruh pimpinan suku dan kabilah diminta mengangkat batu tersebut melalui kedua ujung selendang. Hal ini merupakan penyelesaian dan keputusan yang sangat bijak dan adil dari Muhammad bagi semua pihak, karena tanpa pertumpahan darah, batu Hajar Aswad dapat diletakkan kembali ke tempatnya tanpa ada pihak yang merasa dirugikan (Iqbal, 2000: 13-14).

Buku ini menjelaskan pula perjanjian awal yang terjadi dalam agama Islam adalah kesepakatan dengan penduduk Madinah dan orang-orang Yahudi yang terangkum dalam Piagam Madinah. Piagam Madinah sering juga disebut Konstitusi Madinah, Madinah Charter, atau Watsiqah Madinah dengan isi perjanjiannya sebanyak 47 poin.Piagam Madinah ini menyepakati bahwa jika terjadi perselisihan, maka seluruh pihak yang bertikai harus menyerahkan penyelesaian masalah kepada Nabi Muhammad. Namun, bukan berarti Nabi Muhammad adalah orang yang paling berkuasa.Muhammad adalah sosok yang tidak otokratik 
dan sangat mengutamakan musyawarah. Keputusan akan ditetapkan setelah Muhammad mendengar berbagai pendapat dari para sahabatnya(Iqbal, 2000: 20-25).

Afzal Iqbal juga menjabarkan diplomasi ala Rasulullah yang sangat bertolak belakang dengan diplomasi konvensional yang selama ini dikesankan buruk. Diplomasi Rasulullah mengedepankan sikap sopan dalam hubungan kemanusiaan dan menjaga amanah atas kebenaran, dimana kebenaran akan menang dan kebatilan pasti akan hancur. Nabi Muhammad menganggap diplomasi merupakan sarana untuk mencapai tujuan, dan sarana tersebut sama pentingnya dengan tujuan. Selain kebenaran, Muhammad juga menekankan dan selalu mencontohkan komunikasi yang tepat. Hal ini dibuktikan dengan tindakan Muhammad yang selalu menyampaikan risalah dan wahyu dari Allah sesuai dengan perintah Allah. Muhammad tetap menyampaikan hal-hal baik meski ia mengalami penderitaan yang begitu hebat(Iqbal, 2000: 85).

Dalam berdiplomasi, Nabi Muhammad juga mengajarkan sabar dalam mencapai tujuan. Sabar adalah istiqamah dan penuh ketenangan dalam mencari jalan terbaik untuk mencapai tujuan. Tujuan yang besar akan membutuhkan kapasitas kesabaran yang besar pula. Hal ini juga berkaitan dengan cara berdiplomasi selanjutnya yang dianjurkan Muhammad, yaitu lambat namun pasti. Nabi Muhammad diperingatkan untuk tidak terburuburu dan selalu dalam keadaan yang seimbang dalam mencapai tujuan yang ingin dicapai (Iqbal, 2000: 101104).

Diplomasi menurut Nabi Muhammad juga mengedepankan sikap sederhana dan menjauhi sikap sombong. Sombong adalah sifat buruk yang muncul dari perasaan yang berlebihan terhadap kualitas diri dan kepentingan diri sendiri. Diplomasi dengan sistem kesederhanaan tidak menganggap remeh dan tidak menganggap rendah lawan. Ini tentu bentuk penghargaan Muhammad kepada siapapun yang berdiplomasi dengannya. Bagian penting lainnya dalam diplomasi ala Muhammad adalah sifat loyalitas. Loyalitas adalah sikap setia dan konsisten terhadap kewajiban yang dibebankan pada diri seseorang tanpa melihat resiko yang menimpanya. Diplomat yang memiliki loyalitas tinggi akan siap berkorban demi tercapainya tujuan bangsa dan negaranya(Iqbal, 2000: 104-110). 
3. Teori Diplomasi Bersih dalam Perspektif Islam dari Aspek Ontologi, Epistemologi serta Aksiologi

Dalam membahas diplomasi bersih, maka penulis akan mencoba menelaahnya dari berbagai sisi. Mulai dari sisi ontologi, epistemologi serta aksiologi. Dengan demikian, diplomasi bersih akan terlihat secara spesifik mengenai asalusulnya (ontologi), bagaimana (epistemologi) serta manfaatnya (aksiologi).

\subsection{Aspek Ontologi}

Ontologi merupakan salah satu dari tiga kajian Filsafat Ilmu yang paling kuno dan berasal dari Yunani. Beberapa tokoh terkenal Yunani yang memiliki corak pemikiran ontologis adalah Thales, Plato, dan Aristoteles.Kata ontologi berasal bahasa Yunani, yaitu Onatau Ontos yang artinya ada dan logos artinya ilmu. Dengan demikian, ontologi adalah ilmu mengenai sesuatu yang ada atau prinsip umum mengenai sesuatu yang ada.Ontologi juga merupakan studi mengenai sesuatu yang ada dan tidak ada, dengan demikian ontologi mempelajari mengenai realitas (West dan Turner, 2008: 55). Terdapat pula pengertian yang tidak jauh berbeda, dimana ontologi diartikan sebagai teori tentang "ada", yaitu tentang apa yang dipikirkan dan apa yang menjadi objek pemikiran (Qomar, 2006: 1).

Ontologi dapat dipahami pula sebagai cara pandang terhadap dunia dan pada apa yang membentuk berbagai karakteristik pentingnya. Ontologi juga disebut sebagai filsafat pertama karena tidak mungkin berfilsafat sebelum sifat dari realitas ditentukan (West dan Turner, 2008: 55).

Berdasarkan aspek ontologi, maka asal usul dari diplomasi bersih dalam perspektif Islam berfokus pada ajaran Al-Qur'an dan AlHadist. Jika pada awalnya teori diplomasi konvensional dipahami sebagai seni bermain kalimat bahkan hingga menghalalkan kebohongan demi mencapai tujuan diri sendiri, maka diplomasi bersih bertolak belakang dengan halhal tersebut. Jika pada umumnya diplomasi dilakukan dengan cara apapun agar tujuan pihak tertentu tercapai tanpa mempertimbangkan nasib pihak lain, maka diplomasi bersih dalam perspektif Islam melakukan hal yang berbeda. Tujuan utama dari diplomasi bersih adalah memberikan manfaat tidak hanya bagi diri sendiri, tetapi juga bagi semua pihak yang terlibat atau rahmatan lil 'alamin, baik bagi diri sendiri, pihak musuh, maupun bagi alam semesta(Warsito dan 
Surwandono, 2015: 150).

Dengan adanya diplomasi bersih yang ditinjau dari perspektif Islam, maka penulis berpendapat bahwa diplomasi merupakan proses yang sejatinya mengutamakan keadilan. Tidak hanya berfokus pada keuntungan pihak tertentu, tetapi juga bagi semua pihak yang terlibat di dalam proses diplomasi tersebut. Jika diplomasi bersih diterapkan dengan baik dalam segala urusan hubungan politik luar negeri, maka hampir dapat dipastikan tidak akan lagi terjadi perang fisik maupun perang dingin. Dengan mengutamakan unsur keadilan, maka proses hingga hasil dari diplomasi tidak akan terasa berat sebelah atau hanya menguntungkan pihak tertentu dan memberikan sedikit keuntungan bagi pihak lain.

Makna adil di dalam diplomasi bersih ini dapat dilihat dalam ayat Al-Qur'an, Allah SWT telah memberikan pesannya kepada kita sebagai umat manusia agar berlaku adil. Hal tersebut tertera pada Surah An-Nisa ayat 58 yang terjemahannya adalah sebagai berikut:

"Sesungguhnya Allah menyuruh kamu menyampaikan amanat kepada yang berhak menerimanya, dan (menyuruh kamu) apabila menetapkan hukum di antara manusia supaya kamu menetapkan dengan adil.Sesungguhnya Allah memberi pengajaran yang sebaik-baiknya kepadamu.Sesungguhnya Allah adalah Maha Mendengar lagi Maha Melihat." (QS AN-Nisa 4:58)

Diplomasi bersih melalui perspektif Islam juga menekankan efek kesetaraan dan persamaan antar manusia. Dalam tulisannya, Prof. Dr. Tulus Warsito dan Dr. Surwandono mengatakan bahwa diplomasi bersih menawarkan sisi yang berbeda dengan diplomasi konvensional.Dengan mengusung konsep rahmatan lil alamin, diplomasi Islam bersifat bersih dan egaliter atau sama dan sederajat. Sedangkan hal ini biasanya tidak terdapat dalam diplomasi konvensional yang hanya mencari keuntungan nasionalnya sendiri dan cenderung hipokrit atau munafik serta penuh kepura-puraan dalam proses diplomasinya. Konsep rahmatan lil 'alamindan egaliter yang terkandung dalam diplomasi bersih, juga sudah secara jelas dinyatakan oleh Allah SWT melalui ayat Al-Qur'an.

"Wahai manusia, sesungguhnya Kami menciptakan kamu dari seorang laki-laki dan seorang perempuan dan menjadikan kamu berbangsa-bangsa dan 
bersuku-suku supaya kamu saling kenal-mengenal.Sesungguhnya orang yang paling mulia diantara kamu disisi Allah ialah orang yang paling taqwa diantara kamu. Sesungguhnya Allah Maha mengetahui lagi Maha Mengenal." (QS AlHujuraat 49:13)

\subsection{Aspek Epistemologi}

Epistemologi adalah teori mengenai ilmu pengetahuan, yaitu membahas tentang bagaimana cara mendapatkan pengetahuan dari objek yang dipikirkan. Sebagai sub sistem dalam filsafat, epistemologi pertama kali digagas oleh Plato. Epistemologi berasal dari kata "Episteme" yaitu pengetahuan dan juga "logos" yang bermakna ilmu atau uraian.Sehingga secara etimologi, epistemologi dapat diartikan sebagai teori tentang ilmu pengetahuan atau Theory of Knowledge.

Dalam perjalanannya hingga kini, beberapa ahli mencoba memberikan pengertian yang mendetail mengenai epistemologi. Dagobert D. Runes misalnya, ia mengatakan bahwa epistemologi adalah cabang filsafat yang membahas sumber, struktur, metodemetode dan validitas pengetahuan. Pendapat yang tidak jauh berbeda juga disampaikan oleh
Azyumardi Azra, ia mengatakan bahwa epistemologi adalah ilmu yang membahas mengenai keaslian, pengertian, struktur, metode serta validitas ilmu pengetahuan(Qomar, 2006: 4).

\section{Piagam Madinah}

Dari sisi epistemologi, maka diplomasi bersih dalam perspektif Islam dilihat dan dikaji melalui keaslian atau kebenaran, metode serta validitasnya. Selain melalui ayat Al-Qur'an dalam surah Al-Hujuraat ayat 13 mengenai kesetaraan dan persamaan antarmanusia yang telah dijelaskan di atas, diplomasi bersih sebenarnya telah tergambar jelas dalam Piagam Madinah.

Piagam Madinah bersifat universal, tidak hanya untuk kalangan Muslim semata tetapi untuk kalangan umat dalam artian luas. Pada waktu itu, Madinah tidak hanya dihuni oleh umat Muslim tetapi juga dihuni oleh kaum Anshar, yaitu kaum yang pernah menolong Nabi Muhammad. Madinah tidak pula hanya dihuni oleh kaum Muhajirin atau sahabat nabi yang berasal dari Mekah. Akan tetapi, Madinah kala itu juga dihuni oleh golongan lain dengan beragam agama seperti Yahudi, Nasrani dan bahkan golongan musyrikin yang masih menyembah berhala, serta kaum majusi yang menyembah 
api (Moesa, 2007: 241). Hal ini semakin meneguhkan bahwa visi Islam dalam membangun politik berlandaskan politik kesetaraan. Berbagai golongan tersebut oleh Nabi Muhammad SAW tidak disatukan melalui sentimen agama, melainkan melalui sentimen kepemilikan bersama, untuk bahumembahu mempertahankan Madinah dari segenap ancaman yang datang dari luar (Moesa, 2007: 241-242).

Dalam Piagam Madinah terdapat semangat untuk tidak hanya melindungi umat Islam, melainkan juga menyelamatkan kota Madinah. Sehingga, golongan lain tidak harus di-Islam-kan, tetapi yang jauh lebih penting adalah digugah rasa kepemilikannya terhadap Kota Madinah sebagai tempat tinggal bersama dari ancaman luar, khususnya dari kaum Quraisy Mekah. Dengan demikian, realitas sosial yang terdapat dalam Piagam Madinah adalah pengakuan adanya pluralitas di kehidupan berbangsa dan bermasyarakat karena adanya keragaman agama, keyakinan, kabilah serta latar belakang kehidupan. Itulah sebabnya, dapat dikatakan bahwa Piagam Madinah bukan hanya perjanjian agama, melainkan "kontrak sosial kebangsaan" karena menyangkut aspek hubungan antarumat manusia di dunia atau mu'amalah dunyawiyah(Moesa, 2007: 242-243).

Piagam Madinah terdiri dari 47 poin perjanjian. Dalam bagian ini, penulis hanya akan meyebutkan 20 poin perjanjian tersebut. Agar gambaran mengenai Piagam Madinah menjadi semakin jelas, berikut adalah isi dari 20 perjanjian tersebut(Warsito dan Surwandono, 2015: 155-159):

Dengan Nama Allah Yang Maha Pengasih Lagi Maha Penyayang

Ini adalah kesepakatan yang ditulis oleh Muhammad dengan orang-orang muslim (Mekkah) Quraisy dan Yatsrib serta siapa pun yang mengikuti mereka dan yang menyatakan kesetiaan untuk berjihad bersama mereka.

Mereka adalah satu komunitas (umat) yang berbeda dari masyarakat yang lain.

$\checkmark$ Kaum Muhajirin dari Quraisy, sesuai dengan adat kebiasaan yang berlaku sebelumnya, hendaklah bekerja sama dalam membayar tebusan untuk membebaskan anggota mereka yang ditawan. Tiap-tiap kelompok harus membebaskan anggota yang ditawan dengan cara yang benar dan baik.

$\checkmark \quad$ Bani Auf, sesuai dengan adat ke- 
biasaan yang berlaku, hendaklah bekerja sama dalam mengupayakan pembayaran tebusan anggota mereka yang ditawan. Tiap-tiap kelompok harus membebaskan anggota yang ditawan dengan cara yang baik dan adil sesuai dengan tradisi yang ada di antara orang-orang beriman.

$\checkmark$ Bani Harits, sesuai dengan adat kebiasaan yang berlaku, (sama dengan nomor 3).

$\checkmark \quad$ Bani Saidah, sesuai dengan adat kebiasaan yang berlaku, (sama dengan nomor 3)

$\checkmark$ Bani Jusyam, sesuai dengan adat kebiasaan yang berlaku, (sama dengan nomor 3).

$\checkmark$ Bani An-Najjar, sesuai dengan adat kebiasaan yang berlaku, (sama dengan nomor 3).

$\checkmark$ Bani 'Amr bin 'Auf, sesuai dengan adat kebiasaan yang berlaku, (sama dengan nomor 3 ).

$\checkmark$ Bani An-Nabit, sesuai dengan adat kebiasaan yang berlaku, (sama dengan nomor 3).

$\checkmark$ Bani Aus, sesuai dengan adat kebiasaan yang berlaku, (sama dengan nomor 3).

$\checkmark$ Orang-orang Mukmin tidak boleh membiarkan seseorang terlilit utang, hendaklah mereka memberikan bantuan kepada- nya, berupa pembayaran denda atau tebusan.

$\checkmark$ Seorang Mukmin tidak boleh melakukan tindakan yang tidak baik kepada sesama mukmin lainnya, baik yang merdeka maupun budak.

$\checkmark$ Seorang Mukmin yang bertakwa berhak menentang seseorang yang menyimpang atau berusaha menyebarkan perbuatan dosa, kezaliman, dan kerusakan di antara orang-orang Mukmin. Mereka hendaknya bersatu menghukum mereka, meskipun mereka adalah anak salah seorang dari mereka.

$\checkmark$ Seorang Mukmin tidak dibenarkan membunuh seseorang demi membela orang kafir, juga tidak boleh membantu seorang kafir untuk melawan seorang Mukmin.

$\checkmark \quad$ Perlindungan (dzimmah) Allah hanya satu, Allah berpihak kepada yang lemah dalam menghadapi yang kuat. Seorang Mukmin adalah pelindung dalam pergaulan bagi Mukmin yang lain.

$\checkmark$ Siapa pun dari kaum Yahudi yang mengikuti kita, maka ia memiliki hak yang sama dalam mendapatkan bantuan dan pertolongan sepanjang dia tidak 
melakukan tindakan yang salah dan tidak membantu pihak lain untuk melawan mereka.

$\checkmark$ Kedamaian antarkaum Muslimin adalah satu. Tak seorang Mukmin pun dibenarkan mengadakan perjanjian dengan orang non-Mukmin di saat perang di jalan Allah kecuali atas dasar persamaan dan keadilan.

$\checkmark \quad$ Perdamaian tidak dapat dibagibagi. Hanyaada satuperdamaian bagi kaum Muslimin. Seorang Mukmin tidak dibenarkan membuat perdamaian dengan non-Muslim dalam perang di jalan Allah kecuali atas dasar persamaan dan keadilan.

$\checkmark$ Seorang Mukmin adalah pelindung bagi Mukmin lainnya saat mereka mengorbankan jiwanya di jalan Allah. Dan orang-orang yang bertakwa adalah orang yang paling baik dalam mendapatkan petunjuk.

Diplomasi bersih melalui perspektif Islam hanya penulis fokuskan pada Piagam Madinah. Namun, sebenarnya diplomasi bersih tidak hanya dapat dibuktikan dan digambarkan melalui Piagam Madinah saja, terdapat pula Perjanjian Hudaibiyah yang dapat kita pelajari teknik diplomasinya. Perang Badar dan Perang Uhud juga memiliki kisah yang dapat menggambarkan diplomasi bersih dalam perspektif Islam.

\section{Diplomasi Terbuka}

Secara epistemologi, diplomasi bersih berdasarkan perspektif Islam juga tergambar dalam diplomasi terbuka. Melalui diplomasi terbuka, maka kita akan memperoleh gambaran, bahwa diplomasi bersih yang terkandung dalam diplomasi terbuka merupakan teknik diplomasi yang baik karena mengandung unsur transparan. Diplomasi terbuka juga merupakan lawan dari diplomasi tertutup atau old diplomacy yang ciri khasnya dapat dilihat pada abad ke-20 dimana setiap negara ketika membuat perjanjian dengan negara lain selalu disertai dengan unsur rahasia dan tertutup.

Diplomasi tertutup biasanya dilakukan oleh para kepala negara yang berkumpul dan membuat suatu keputusan tanpa diketahui rakyatnya. Sifat sangat eksklusif dalam diplomasi tertutup membuat rakyat akan menanggung risiko jika suatu saat terjadi perang akibat kesepakatan atau perjanjian mengenai keamanan gagal dicapai oleh kepala negaranya. Hal ini berbeda dengan diplomasi terbuka, dimana rakyat dapat mengetahui hasil-hasil diplomasi 
beserta proses perundingan yang berlangsung. Tak mengherankan jika diplomasi terbuka mendapat respons dan sambutan yang positif dari masyarakat dunia(Rumintang, 2008: 289-30).

Diplomasi terbuka juga didukung oleh perkembangan zaman yang semakin maju. Dua hal yang menjadi faktor penentu kuatnya diplomasi terbuka adalah revolusi teknologi informasi dan meningkatnya peran media massa.

\section{a. Revolusi Teknologi Informasi}

Perubahan mendasar dalam cara, metode, hingga aktor dari diplomasi tertutup ke era diplomasi terbuka terjadi setelah adanya revolusi teknologi informasi. Hal ini ditandai dengan terbukanya akses informasi seluas-luasnya, tidak hanya eksklusif bagi elite pemerintahan, tetapi juga bagi seluruh rakyat di berbagai belahan dunia.Revolusi teknologi informasi juga erat kaitannya dengan tersedianya jaringan komputer dan elektronik atau internet yang semakin memudahkan akses, manajemen dan penyebarluasan informasi (Hermawan, 2007: 59$60)$.

\section{b. Meningkatnya Peran Media Massa}

Teknologi media massa yang berkembang dengan pesat memungkinkan informasi dapat diakses dengan mudah, cepat dan berbiaya rendah. Peran media massa pada masa ini juga disadari sebagai salah satu faktor kunci penentu keberhasilan diplomasi terbuka. Seperti pernyataan Lord Palmerston bahwa opini lebih kuat daripada tentara. Hal ini mengartikan bahwa media massa memiliki kekuatan penuh dalam membangun dan menciptakan opini publik. Opini publik inilah yang merupakan elemen penting bagi pemerintah agar proses dan hasil diplomasi mendapat simpati dan dukungan rakyat(Hermawan, 2007: 60-62).

Media massa dalam ranah diplomasi juga merupakan sumber informasi untuk menyediakan bahan dalam negosiasi, selain juga fungsinya sebagai mediator dalam proses diplomasi. Media massa melalui fungsinya juga memiliki peranan penting dalam menyiarkan proses diplomasi. Dengan demikian, kebijakan yang disepakati dalam diplomasi harus konsisten dan mampu mempersuasi warga dunia.

\subsection{Aspek Aksiologi}

Aksiologi berasal dari bahasa Yunani dan terdiri dari kata "axios" yang artinya nilai serta "logos" yang artinya ilmu. Dengan demikian, maka aksiologi adalah ilmu tentang 
nilai. Aksiologi juga dapat dipahami sebagai teori mengenai nilai yang membahas tentang manfaat atau kegunaan maupun fungsi dari objek yang dipikirkan(Qomar, 2006: 1). Jujun S. Suriasumantri berpendapat bahwa aksiologi adalah teori nilai yang berkaitan dengan kegunaan dari pengetahuan yang diperoleh (Zamroni, 2009: 101).

Aksiologi melihat sisi manfaat dan nilai yang terkandung dalam diplomasi bersih melalui perspektif Islam. Dengan menerapkan negosiasi berdasarkan diplomasi bersih, maka manfaatnya adalah berkurang atau bahkan hilangnya upaya persuasi yang mengandung kebohongan. Negosiasi akan dilihat sebagai upaya yang tidak hanya menguntungkan satu pihak saja, tetapi juga menguntungkan bagi pihak lain. Keuntungan yang seragam akan menciptakan rasa adil di semua pihak yang terlibat dalam diplomasi. Dengan demikian, diharapkan tidak ada rasa iri ataupun dendam, melainkan rasa puas yang sama rata.

Segala proses diplomasi bersih dalam perspektif Islam yang mengutamakan kesetaraan, persamaan, dan keadilan tentu akan meminimalisir terjadinya konflik ataupun perang. Hubungan antarnegara ataupun hubungan antar- aktor diplomasi akan semakin erat terjalin. Hubungan yang baik antar-negara atau antar-aktor $\mathrm{HI}$ akan memudahkan suatu negara melakukan perjanjian dan kesepakatan dalam berbagai bidang.

\section{Kesimpulan}

Islam sejatinya sudah menjelaskan banyak hal dalam Al-Qur'an dan Hadist, termasuk soal teknik, metode dan cara yang baik dalam melakukan negosiasi dan diplomasi. Jika kita menelaah berbagai ayat Al-Qur'an dan Hadist, maka sebenarnya diplomasi bersih sudah ada sejak Nabi Muhammad. Hal itu juga dibuktikan melalui berbagai pemikiran hingga tindakan yang Muhammad lakukan dalam menyelesaikan suatu permasalahan. Tidak menyertakan sikap hipokrit dan manipulatif, Nabi Muhammad ternyata mampu menyelesaikan banyak hal dengan baik.

Menerapkan diplomasi bersih sesuai dengan perspektif Islam merupakan cara ampuh nan efektif penyelesaian masalah tanpa masalah karena segala proses diplomasi dilakukan secara terbuka, transparan, adil, sama rata dan tidak hanya menguntungkan diri sendiri, tetapi juga pihak lain dan alam semesta. Hal ini berbeda dengan diplomasi konvensional yang masih 
mengandalkan seni bermain kata dan kalimat, dimana kebohongan sangat mungkin untuk terjadi.

\section{Daftar Pustaka}

\section{Sumber Buku:}

Iqbal, Afzal. 2000.Diplomasi Islam. Jakarta: Pustaka Al-Kautsar.

M. Snow, Donald dan Eugene Brown. 2000. International Relations: The Changing Contours of Power. Longman.

Moesa, Ali Maschan. 2007.

Nasionalisme Kiai. Konstruksi Sosial Berbasis Agama. Yogyakarta: LkiS.

Momengoh, Nick Parfait. 2013. Secret Diplomacy: The Practice of Back Channel. New Jersey: Newark.

Qomar, Mujamil. 2006. Epistemologi Pendidikan Islam. Dari Metode Rasional Hingga Metode Kritik. Jakarta: Erlangga.

P. Hermawan, Yulius. 2007. Transformasi dalam Studi Hubungan Internasional: Aktor, Isu dan Metodologi. Yogyakarta: Graha Ilmu.

Roy, S. L. Diplomasi. 1991. Jakarta: Rajawali Pers.

Rumintang, Lusiana. 2008. Bekerja sebagai Diplomat. Jakarta: Erlangga.
S. Levy, Jack. 2008. Deterrence and Coercive Diplomacy: The Contributions of Alexander George.

West, Richard dan Lynn H. Turner. 2008.Pengantar Teori Komunikasi. Jakarta: Salemba Humanika.

Zamroni, Muhammad. 2009. Filsafat Komunikasi: Pengantar Ontologis, Epistemologis, Aksiologi. Yogyakarta: Graha Ilmu.

\section{Sumber Internet:}

D'Hooghe, Ingrid. 2007. The Rise of China's Public Diplomacy. The Hague, Netherlands Institue of International Relations.Diakses dari http://www.clingendael.nl/ sites/default/files/20070700_ cdsp_paper_hooghe.pdf, pada Jumat 29 April 2016, pukul 21.59 WIB.

Tulus Warsito dan Surwandono. 2015. "Diplomasi Bersih" Dalam Perspektif Islam. Diakses dari http://ejournal.uin-suka.ac.id/ index.php/thaqafiyyat/article/ viewFile/627/pdf_32, pada 23 April 2016, pukul 10.00 WIB. 